Artykuły

Studia luridica Lublinensia vol. XXV, 3, 2016

DOI: $10.17951 /$ sil.2016.25.3.179

\title{
Paweł Cichoń
}

Uniwersytet Jagielloński

pawel.cichon@uj.edu.pl

\section{Z orzecznictwa Dyrekcji Policji Wolnego Miasta Krakowa - casus Oszyków}

\author{
From the Case-law of Directorate of Police \\ in the Free City of Cracow - the Oszyk's Case
}

\section{STRESZCZENIE}

Artykuł przedstawia działalność sądowniczą Dyrekcji Policji Wolnego Miasta Krakowa na przykładzie sprawy Oszyków z 1842 r., tj. żydowskiego małżeństwa, które zawarło ślub rytualny bez wcześniejszego obowiązkowego ślubu cywilnego. Osoby zawierające takie małżeństwo popełniały przestępstwo zaliczane do kategorii ciężkich przestępstw policyjnych. W opracowaniu przedstawiono przepisy, które określały kary za tego rodzaju przestępstwo. Omówiono również przebieg postępowania sądowego w sprawie Oszyków i wskazano na inne tego typu sprawy prowadzone w Dyrekcji Policji w 1842, 1844 i 1845 r.

Słowa kluczowe: Wolne Miasto Kraków; administracja; sądownictwo; Dyrekcja Policji; małżeństwo rytualne żydowskie; prawo karne

Dyrekcja Policji, powołana do życia na mocy rozporządzenia Senatu Rządzącego z dnia 13 lipca 1827 r. ${ }^{1}$, rozpoczęła swoją działalność już 1 sierpnia 1827 r. ${ }^{2}$ Przejęła ona nie tylko dotychczasowe zadania Biura Policji Pośredniej, ale również w kolejnych latach powierzano jej nowe zadania z zakresu porządku i bezpieczeństwa publicznego. Oprócz zadań typowo administracyjnych, Dyrekcji Policji przekazywano też zadania o charakterze sądowniczym, między innymi orzekanie w sprawach ciężkich przestępstw policyjnych ${ }^{3}$.

${ }^{1}$ Dz. Praw RK z 1827 r., nr 3344 D.G.S.

2 P. Cichoń, Dyrekcja Policji Wolnego Miasta Krakowa 1827-1846. Studium historyczno-prawne, Kraków 2014, s. 90.

${ }^{3}$ Powierzenie zadań sądowniczych organowi administracyjnemu, jakim niewątpliwie była 
Decyzja o przyznaniu Dyrekcji Policji powyższych kompetencji zapadła w 1838 r. w związku z likwidacją sądów podsędkowskich. Aktem prawnym, na mocy którego przyznano tej Dyrekcji uprawnienia jurysdykcyjne w sprawach o ciężkie przestępstwa policyjne, było rozporządzenie Senatu Rządzącego Urządzenie biegu służby sprawiedliwości karnej z dnia 2 lipca 1839 r. (pkt 3)4. Od tego momentu Dyrekcja Policji nie tylko prowadziła dochodzenia (czym zajmowała się już od 1833 r.), ale też merytorycznie rozpoznawała i rozstrzygała te sprawy. Zmiany zainicjowane wyżej wymienionym Urządzeniem były podyktowane chęcią zwiększenia przez rządzących bezpieczeństwa wewnętrznego kraju i „spokojności Państw sąsiednich”. Wiązało się to także z narastającymi w Rzeczypospolitej Krakowskiej tendencjami reakcyjnymi i wstecznym kierunkiem reform sądowo-administracyjnych.

„Rozciągłość i granice jurysdykcji” Dyrekcji Policji, „tak pod względem ustanowienia istoty czynu przy zbrodniach lub ciężkich przestępstwach policyjnych, jak pod względem karania tych ostatnich", miał określić nowy statut tej Dyrekcji (pkt. 3 Urządzenia).

Statut urządzający Dyrekcję Policji Wolnego Miasta Krakowa z dnia 18 lutego 1840 r. faktycznie określił zakres jej służby „karząco-sądowej”, zaliczając do niej między innymi orzekanie we wszystkich sprawach ciężkich przestępstw policyjnych popełnionych na obszarze Miasta Krakowa oraz gmin administracyjnie włączonych do tego miasta $(\S 14)^{5}$. Kolejny Statut organiczny dla władz sądowych kraju Wolnego Miasta Krakowa, z dnia 25 stycznia 1842 r., utrzymał powyższe kompetencje jurysdykcyjne Dyrekcji Policji $(\S 16)^{6}$.

Materialnoprawną podstawą działalności Dyrekcji Policji w zakresie ciężkich przestępstw policyjnych był austriacki kodeks karny z 1803 r. (dalej jako: k.k.) ${ }^{7}$,

Dyrekcja Policji, nie było rozwiązaniem szczególnie oryginalnym w pierwszej połowie XIX w., gdyż z taką praktyką można się było spotkać zarówno w czasach Księstwa Warszawskiego, jak i Królestwa Polskiego. Szerzej na ten temat zob. A. Korobowicz, W. Witkowski, Funkcje sądowe organów administracji lokalnej w Księstwie Warszawskim i Królestwie Polskim, „Czasopismo Prawno-Historyczne" 1993, t. 45, z. 1-2, s. 139-157.

${ }^{4}$ Dz. Praw z 1839 r., nr 23, dalej jako: Urządzenie; S. Salmonowicz, Prawo karne oświeconego absolutyzmu. Z dziejów kodyfikacji karnych przełomu XVIII/XIX w., Toruń 1966, s. 143-147; L. Pauli, Austriacki kodeks karny z 1803 r. w Wolnym Mieście Krakowie (1815-1833), cz. 1, „Zeszyty Naukowe Uniwersytetu Jagiellońskiego. Prace Prawnicze” 1968, z. 40, s. 16-17.

${ }^{5}$ Dz. Praw z 1840 r., nr 10 D.K., dalej jako: Statut Dyrekcji Policji.

${ }^{6}$ Dz. Praw z 1842 r., nr 3 D.K. Statut sądowy w zakresie składu orzekającego co do ciężkich przestępstw policyjnych oraz zasad postępowania w związku z prowadzeniem postępowań przeciwko zbrodniom odsyłał do odpowiednich przepisów Statutu Dyrekcji Policji (§ 19).

${ }^{7}$ W edycjach zawierających polski przekład kodeksu z 1803 r. nadano mu nazwę Księga ustaw na zbrodnie $i$ ciężkie policyine przestępstwa. W niniejszym artykule posługuję się przekładem polskim, opublikowanym w 1804 r. w Krakowie w drukarni Józefa Jerzego Trasslera w dwóch odrębnych częściach: O zbrodniach (cz. 1) i Księga ustaw o ciężkich przestępstwach policyinych i o sposobie z temiż postępowania (cz. 2). 
który miał obowiązywać w Wolnym Mieście Krakowie tymczasowo, do czasu uchwalenia przez Zgromadzenie Reprezentantów własnego kodeksu karnego, do czego jednak nigdy nie doszło. Wobec tego przez cały okres istnienia Rzeczypospolitej Krakowskiej obowiązywał ten właśnie kodeks karny, który wraz z nowelą lipcową z 1810 r. (tj. dekretem króla saskiego i księcia warszawskiego z dnia 26 lipca $1810 r^{8}{ }^{8}$ ) stanowił podstawowe źródło prawa karnego. Szczególne znaczenie w działalności orzeczniczej Dyrekcji Policji miała druga część kodeksu karnego, poświęcona ciężkim przestępstwom policyjnym, a zwłaszcza wydział drugi części drugiej, zawierający zasady postępowania związane z orzekaniem w tych sprawach.

Przyznanie Dyrekcji Policji tego rodzaju uprawnień stanowiło także w pewnym sensie powrót do pierwotnego założenia austriackiego kodeksu karnego z 1803 r. Zgodnie z tym założeniem w sprawach o ciężkie przestępstwa policyjne jurysdykcja powinna przysługiwać właściwym terytorialnie władzom politycznym, tj. administracyjnym.

W Archiwum Narodowym w Krakowie znajduje się zespół archiwalny pod nazwą Akta Dyrekcji Policji Wolnego Miasta Krakowa 1818-18489, w którym zachowało się kilkaset wyroków wydanych przez ten organ w sprawach o ciężkie przestępstwa policyjne oraz nieliczne wyroki wydane w trybie rewizyjnym przez organy II instancji.

Wśród nich znajduje się wyrok z dnia 31 sierpnia 1842 r. (nr 13688), wydany w sprawie Samuela i Jachet Oszyków, związanej z potajemnym zawarciem przez nich rytualnego małżeństwa bez poprzedzającego ślubu cywilnego ${ }^{10}$. Sprawa ta jest interesująca głównie $\mathrm{z}$ dwóch powodów. Po pierwsze, była to jedyna sprawa (spośród tych, w których zapadły wyroki znajdujące się w wyżej wymienionym zespole archiwalnym), w której Dyrekcja Policji z własnej inicjatywy orzekła za takie przestępstwo łagodniejszą karę niż w innych tego typu przypadkach. Po

${ }^{8}$ Dekret ten został uchylony powołanym wcześniej Urządzeniem biegu służby sprawiedliwości karnej z dnia 2 lipca 1839 r. (Dz. Praw z 1839 r., nr 23, pkt 1). Co ciekawe, dekret ten odzyskał moc prawną w okresie powstania krakowskiego, co nastąpiło na podstawie art. 5 rozporządzenia dyktatora z dnia 26 lutego 1846 r. Zob. S. Wachholz, Akty prawne Rewolucji Krakowskiej z roku 1846, „Czasopismo Prawno-Historyczne” 1956, t. 8, z. 1, s. 335; L. Pauli, Austriacki kodeks karny z 1803 r. w Wolnym Mieście Krakowie (1815-1833), cz. 1, s. 33-37, 76; idem, Austriacki kodeks karny z 1803 r. w Wolnym Mieście Krakowie (1815-1833), cz. 2, „Zeszyty Naukowe Uniwersytetu Jagiellońskiego. Prace Prawnicze" 1970, z. 46, s. 120-122; W.M. Bartel, Ustrój i prawo Wolnego Miasta Krakowa (1815-1846), Kraków 1976, s. 106; W. Sobociński, Historia ustroju i prawa Księstwa Warszawskiego, Toruń 1964, s. 276.

9 Archiwum Narodowe w Krakowie, Ekspozytura w Spytkowicach (dalej jako: ANKr), Archiwum Wolnego Miasta Krakowa (dalej jako: WMK) - zespół nr 200. W aktach WMK III/18/13, III/18/14 i III/18/15 zachowały się jedynie wyroki Dyrekcji Policji wydane w sprawach ciężkich przestępstw policyjnych w latach 1842-1846. Szerzej o działalności jurysdykcyjnej Dyrekcji Policji zob. P. Cichoń, op. cit., s. 349-407.

${ }^{10}$ ANKr, WMK - III/18/15, k. 971-976. 
drugie, w sprawie tej zachował się protokół z przebiegu narady członków składu orzekającego, dzięki czemu można ustalić motywy, którymi kierowała się Dyrekcja Policji, wydając taki wyrok. Z dostępnych informacji możemy też wyciągnąć wnioski dotyczące przebiegu tego postępowania, co daje nam pewne wyobrażenie o kulisach działalności Dyrekcji Policji.

Chcąc przybliżyć casus Oszyków, należy rozpocząć od wskazania, że zawieranie rytualnych małżeństw przez osoby wyznania mojżeszowego bez uprzedniego ślubu cywilnego było czynem zabronionym i traktowano je jako ciężkie przestępstwo policyjne „przeciw obyczajności publicznej”, stypizowane w $§ 252$ cz. 2 k.k. Przepis ten brzmiał:

Kto się, utaiwszy wiadomą sobie z prawa do małżeństwa przeszkodę, zaślubił, nie otrzymawszy na to wprzód przyzwoitej dyspensy, albo w obcy kraj udał, zamiarem zawarcia tamże małżeństwa, które podług ustaw krajowych miejsca mieć nie mogło, ten aresztem ścisłym od trzech do sześciu miesięcy, a uwodzący zawsze ostrzej ukarany być powinien; areszt zaś natenczas zaostrzyć jeszcze należy, gdyby przeszkoda przed jedną stroną była utajona i taż niewinnie takowym sposobem do małżeństwa nieważnego uwiedzioną została.

W myśl Statutu urządzającego starozakonnych w Wolnym Mieście Krakowie z dnia 1 czerwca $1817 \mathrm{r}$. Żydzi byli zobowiązani do zawierania małżeństw przed osobnym urzędnikiem stanu cywilnego ${ }^{11}$.

W okresie Wolnego Miasta Krakowa obowiązywały aż trzy kolejne akty prawne regulujące konsekwencje prawne zawarcia potajemnego związku małżeńskiego przez Izraelitów bez uprzedniego ślubu cywilnego, które stanowiły lex specialis w stosunku do przepisów kodeksu karnego z 1803 r.

Pierwszym aktem prawnym była ustawa Zgromadzenia Reprezentantów z dnia 28 grudnia 1821 r. - Prawo dla zapobieżenia nadużyciom starozakonnych, zawierających potajemnie w drodze religijnej małżeństwa, obowiązująca od dnia 1 lutego 1822 r. $^{12}$ Zgodnie z art. 5 tej ustawy za zawarcie potajemnego związku małżeńskiego, bez uprzedniego zawarcia go przed świeckim urzędnikiem stanu cywilnego, przewidziano karę grzywny w wysokości 1000 złp ${ }^{13}$, z których połowa

${ }^{11}$ Dz. Roz. Rządowych WMK 1817, nr 1358; L. Pauli, Austriacki kodeks karny z 1803 r. w Wolnym Mieście Krakowie (1815-1833), cz. 2, s. 103; S. Wachholz, Rzeczpospolita Krakowska. Okres od 1815 do 1830 r., Warszawa 1957, s. 366, 375; J.M. Małecki, Żydzi krakowscy w XIX wieku, wyjście z getta, [w:] Wspólnoty lokalne $i$ środowiskowe w miastach i miasteczkach ziem polskich pod zaborami i po odzyskaniu niepodległości. Studia nad dziejami miast i mieszczaństwa, Toruń 1998, s. 146-147; A. Jakimyszyn, Żydzi krakowscy w dobie Rzeczypospolitej Krakowskiej. Status prawny, przeobrażenia gminy, system edukacyjny, Kraków - Budapeszt 2008, s. 77-79. Problem zawierania małżeństw religijnych bez poprzedniego ślubu cywilnego, jak się okazało, dotyczył również chrześcijan. Zob. P. Cichoń, op. cit., s. 403.

12 Dz. Roz. Rządowych WMK 1822, nr 4831 D.G.S.

${ }^{13}$ Była to bardzo wysoka kara, którą ze względu na duże ubóstwo ludności żydowskiej mogli zapłacić tylko nieliczni. Dla wyobrażenia sobie wysokości kary można podać przykład, że podrewizor wyznania mojżeszowego, zatrudniony w Dyrekcji Policji, zarabiał rocznie 750 złp. Ibidem, s. 169. 
przypadała Skarbowi Państwa, a połowa - donosicielowi. W przypadku niemożności zapłacenia kary pieniężnej ustawa przewidziała karę aresztu poprawczego według przelicznika 5 dni za każde 30 złp. Podobną karę ponosili starozakonni duchowni i świadkowie, którzy brali udział w takiej ceremonii religijnej.

Kolejnym aktem prawnym, który uchylił art. 5 wyżej wymienionej ustawy, była ustawa Zgromadzenia Reprezentantów z dnia 9 marca 1838 r. $^{14}$, która weszła w życie z dniem 1 kwietnia 1838 r. i przewidywała za zawarcie małżeństwa religijnego „bez poprzedniego na drodze cywilnej spisania przed właściwym urzędnikiem stanu cywilnego kontraktu małżeństwa" karę w wysokości 1000 złp, a gdy skazani nie byli jej w stanie zapłacić, zamieniano ją na karę aresztu poprawczego przez 6 miesięcy. Analogiczną karę miał ponieść urzędnik religijny i świadkowie, którzy asystowali podczas uroczystości religijnej (art. 1). Prawnym dowodem popełnienia tego rodzaju przestępstwa w przypadku „braku własnego oskarżonych przyznania albo dowodu ze świadków lub współwinnych", mógł być zbieg dwóch okoliczności następujących obok wspólnego pożycia: a) wychowanie potomstwa, b) strzyżenie włosów przez kobietę i c) używanie talitu przez mężczyznę.

Ostatnim aktem prawnym, który regulował tę kwestię, była ustawa z dnia 5 lipca 1844 r., która weszła w życie z dniem 1 sierpnia 1844 r. ${ }^{15}$ Ustawa ta w zakresie karania osób wyznania mojżeszowego, które potajemnie zawarły małżeństwo religijne bez wcześniejszego ślubu cywilnego, odsyłała bezpośrednio do $\S 252$ cz. 2 k.k. Uchyliła ona również wcześniejszą ustawę z 1838 r. dotyczącą kar za takie przestępstwo. Tym samym zrezygnowano z możliwości wymierzania kary grzywny przewidzianej $\mathrm{w}$ tej ustawie. Wobec tego winni popełnienia tego rodzaju przestępstwa mogli otrzymać jedynie karę aresztu ścisłego od 3 do 6 miesięcy. Warto dodać, że ustawa z 1844 r. utrzymała w mocy wskazane wyżej okoliczności przewidziane we wcześniejszej ustawie, które traktowano jako poszlaki zawarcia potajemnego małżeństwa $(\S 2)$.

Dyrekcja Policji była organem właściwym do osądzenia i wymierzenia kary Oszykom zgodnie z obowiązującym wówczas Statutem organicznym dla władz sądowych kraju Wolnego Miasta Krakowa z dnia 25 stycznia 1842 r. ${ }^{16} \mathrm{Z}$ kolei zgodnie ze Statutem Dyrekcji Policji z 1840 r. orzekanie w sprawach ciężkich przestępstw policyjnych należało do Wydziału Sądowniczego tej Dyrekcji (§ 14) ${ }^{17}$. Tryb przeprowadzania inkwizycji $\mathrm{w}$ takich sprawach określały odrębne przepisy (wydział 2 cz. 2 k.k.), które Wydział Sądowniczy był zobowiązany zastosować (§ 15). Postępowanie w sprawach ciężkich przestępstw policyjnych było oparte

${ }^{14}$ Dz. Praw 1838, nr 539 D.G.S.

15 Dz. Praw z 1844 r., nr 3106 D.G.S.

${ }^{16}$ Dz. Praw z 1842 r., nr 3 D.K.

${ }^{17}$ Dz. Praw z 1840 r., nr 10 D.K. Choć uprawnienia sądownicze były delegowane na Wydział Sądowniczy, to jednak był to tylko przejaw dekoncentracji wewnętrznej, opartej na zasadzie resortowości, gdyż całość kompetencji przysługiwała wyłącznie Dyrekcji Policji. 
na zasadach procesu inkwizycyjnego, ale było znacznie bardziej uproszczone w porównaniu z postępowaniem sądowym w sprawach zbrodni ${ }^{18}$. Przy ocenie zebranego w trakcie dochodzenia materiału dowodowego Dyrekcja Policji była związana sformułowanymi w kodeksie regułami dowodowymi. Kodeks opierał się na tzw. negatywnej teorii dowodów formalnych, określającej z góry wiarygodność i moc poszczególnych dowodów w zależności od ich ilości i rodzaju, a nie rzeczywistej wartości ${ }^{19}$. Po przeprowadzeniu dochodzenia Dyrekcja Policji albo kwalifikowała czyn przestępny jako ciężkie przestępstwo policyjne i wydawała wyrok skazujący, albo wobec braku znamion czynu zabronionego wydawała wyrok uniewinniający. W przypadku „braku prawnych dowodów”, a więc braku określonych w kodeksie karnym dowodów popełnienia przestępstwa, „znosiła inkwizycję”, czyli umarzała postępowanie karne.

Stan faktyczny w sprawie Oszyków znamy jedynie z informacji zawartych na formularzu wyroku wydanego przez Dyrekcję Policji oraz z protokołu narady składu orzekającego. Sprawa zawisła przed Dyrekcją Policji w sierpniu 1842 r. w związku z popełnieniem na terenie Krakowa przez małżonków Samuela i Jachet Oszyków przestępstwa z § 252 cz. 2 k.k.

Otóż wspomniani małżonkowie przed ośmioma laty (czyli w 1834 r.) zawarli potajemnie małżeństwo w obrządku religijnym, bez poprzedzającego je ślubu cywilnego. $Z$ dostępnych informacji nie sposób stwierdzić, dlaczego nie dopełnili tego wymogu. Powody mogły być różne. Najczęściej w tego typu sprawach było to spowodowane ogólną niechęcią ludności żydowskiej do przepisów, które traktowano jako szczególnie uciążliwe, zwłaszcza w połączeniu z koniecznością ubiegania się o urzędowe pozwolenie (konsens) na zawarcie małżeństwa ${ }^{20}$. Uzyskanie takiego zezwolenia wiązało się z koniecznością spełnienia przez wnioskodawcę różnych warunków formalnych, których nie wszyscy Żydzi mogli spełnić. Obowiązywał cenzus wieku, a przede wszystkim cenzus majątkowy. Kandydaci na przyszłych małżonków musieli wykazać się posiadaniem odpowiedniego zawodu lub majątku, który pozwoliłby im na utrzymanie przyszłej rodziny ${ }^{21}$. W związku z tym zapewne unikano ubiegania się o takie zezwolenie, obawiając się wydania odmownej decyzji oraz narażenia się na łatwe sprawdzenie, czy wnioskodawca nie zawarł wbrew zakazowi jedynie potajemnego ślubu wyznaniowego.

\footnotetext{
${ }^{18}$ A. Dziadzio, Powszechna historia prawa, Warszawa 2008, s. 431.

${ }^{19}$ L. Pauli, Austriacki kodeks karny z 1803 r. w Wolnym Mieście Krakowie (1815-1833), cz. 1,
} s. 17.

${ }^{20}$ Początkowo konsens wydawali wójtowie w gminach zgodnie ze Statutem urządzającym starozakonnych z 1817 r. (Dz. Roz. Rządowych WMK z 1817 r., nr 1358). Po zniesieniu instytucji wójtów Dyrekcja Policji wnioskowała w Krakowie do Wydziału Spraw Wewnętrznych i Policji o wydanie starozakonnym zezwolenia na zawarcie związku małżeńskiego (Dz. Rządowy WMK z 1839 r., nr 25, s. 98, nr 1855 D.G.S.). Zob. A. Jakimyszyn, op. cit., s. 114.

${ }^{21}$ Ibidem, s. 89-93; B. Małecka, Sytuacja prawna ludności żydowskiej w Rzeczypospolitej Krakowskiej w świetle rozporządzeń rządowych, „Studia Historyczne” 1991, s. 374-375. 
Po ujawnieniu sprawy Dyrekcja Policji wszczęła postępowanie przeciwko Samuelowi i Jachet Oszykom, w toku którego przeprowadzono inkwizycję, czyli dochodzenie. W tego typu sprawach inkwizycja trwała zwykle bardzo krótko. W sprawie Oszyków - od 19 do 20 sierpnia 1842 r. Oboje małżonkowie nie zaprzeczali stawianym zarzutom i od razu przyznali się do winy.

Narada składu orzekającego, z udziałem sekretarza, odbyła się w dniu 31 sierpnia 1842 r. Pierwszy zabrał głos referent Stanisław Bogdziński, któremu przydzielono sprawę. Przedstawił on swoją opinię co do prawnej kwalifikacji czynu. Wskazał na odpowiednie przepisy prawa, dotychczasowy przebieg postępowania oraz na okoliczności mające wpływ na wymiar kary. Zwrócił uwagę, że małżonkowie dopuścili się czynu zabronionego w czasie obowiązywania ustawy z $1821 \mathrm{r}$. i w związku z tym wskazał, że należy wobec nich zastosować przepisy tej ustawy, a nie nowej ustawy z 1838 r., obowiązującej w dacie wyrokowania. Stanowisko referenta było jak najbardziej zasadne, gdyż prawo karne obowiązujące w Wolnym Mieście Krakowie stało na gruncie zakazu retroakcji oraz zasady nullum crimen sine lege i nulla poena sine lege. Wobec tego rozpatrywanie tego typu spraw wiązało się z koniecznością ustalenia daty zawarcia ślubu religijnego, gdyż konsekwencje prawne związane z tym przestępstwem, a zwłaszcza wysokość kary, były ustalane według stanu prawnego obowiązującego $\mathrm{w}$ dacie dopuszczenia się czynu przestępnego.

Komisarz S. Bogdziński wskazał też, że ze względu na ubóstwo Oszykowie nie będą w stanie zapłacić kary pieniężnej, w związku z tym uważał, że powinni zostać od razu skazani na standardowo wymierzaną w tego typu sprawach karę, tj. 83 dni aresztu. W tym zakresie odwołał się do treści art. 5 ustawy z $1821 \mathrm{r}$.

Po wysłuchaniu opinii referenta dyrektor policji Filip Wolfarth ${ }^{22}$ stwierdzil, że zgadza się z jego opinią, iż na podstawie $\S 352$ cz. 2 k.k. są ,,prawnie przekonani, że naruszyli art. 5 ustawy sejmowej z 1821 r.”. Dyrektor Policji zauważył też, że wyżej wymienieni od razu przyznali się do winy, nie utrudniali inkwizycji, są biedni i utrzymują się jedynie z zarobku, poza tym mają dwoje małoletnich dzieci. W związku z tym uznał, że zastosowanie aresztu w wysokości proponowanej przez S. Bogdzińskiego ,przyniosłoby znaczną szkodę w ich sposobie życia i wystawiłoby ich rodzinę na nędzę”. Uważał, że należy ,zastosować § 23, lit. b, cz. 2 k.k. ${ }^{23}$,

${ }^{22}$ Filip Wolfarth był dyrektorem policji w latach 1839-1845. Zob. P. Cichoń, op. cit., s. 140.

${ }^{23}$ Przepis § 23 brzmiał: „W następujących zaś szczególnych okolicznościach kara przez ustawę postanowiona, odmieniona być ma: a) kiedy kara pieniężna w stanie majątku lub sposobie do życia mającego być na karę skazanym albo dla onegoż familii wielkim byłaby uszczerbkiem; b) kiedy przez długość czasu prawem postanowionego aresztu zarobek podpadającego karze albo onegoż familii mógłby albo upaść, albo do nieładu być przywiedzionym; c) kiedy ustawą kara cielesna na plagi jest postanowiona; stan zaś ciała i zdrowie skazanego takowego ukarania nie dozwala. W pierwszym przypadku zamiast kary pieniężnej kara aresztu w miarę zasądzona być ma; w drugim przypadku czas długości kary skrócony, a na miejsce onejże, podług okoliczności osoby i stanu ciała, cięższa robota lub cielesna chłosta, albo post postanowiony będzie; w trzecim przypadku chłosta cielesna na karę aresztu, mając jednak wzgląd na sposób zarobkowy karze podpadającego, zamieniona być powinna". 
i rygor aresztu zmniejszyć do 1 miesiąca z obostrzeniem przez post raz na tydzień stosownie do $\S 20$ ". Był też zdania, aby małżonkowie karę odbywali pojedynczo, po kolei, aby ich dzieci nie były pozbawione opieki i żeby każdemu zapewnić możliwość dalszego zarobkowania. Trzecim członkiem rozpoznającym wspomnianą sprawę był komisarz Jan Cukrowicz, który przychylił się do stanowiska dyrektora policji.

Tego samego dnia Dyrekcja Policji, działając kolegialnie w trzyosobowym składzie (komisarze S. Bogdziński oraz J. Cukrowicz), z udziałem dyrektora policji F. Wolfartha, większością głosów, czyli zgodnie z obowiązującymi przepisami prawa (§ 16 Statutu Dyrekcji Policji), podjęła decyzję o wymierzeniu oskarżonym kary aresztu w wysokości 1 miesiąca z zaostrzeniem przez post raz na tydzień. Skazani małżonkowie mieli odbywać karę osobno.

Powyższa historia pokazuje, że Dyrekcja Policji, wymierzając Samuelowi i Jachet Oszykom karę aresztu, wzięła pod uwagę fakt, iż dobrowolnie przyznali się do winy oraz uwzględniła dyspozycję z $§ 23$ lit. b cz. 2 k.k. i tym samym dokonała indywidualizacji kary z uwzględnieniem sytuacji życiowej skazanych. Można więc stwierdzić, że wzięto pod uwagę utylitarny charakter represji karnej, która powinna być proporcjonalna i współmierna do przestępstwa.

W przedmiotowej sprawie podejrzany był również Jakub Kuplik, któremu zarzucano „wspólnictwo” w przestępstwie przez udzielenie potajemnego ślubu. Oskarżony zaprzeczał jednak tym zarzutom, w związku z czym, nawet na podstawie „zbiegu okoliczności”, nie było możliwości ustalenia jego winy. Podczas narady składu orzekającego w sprawie Oszyków dyrektor policji zwrócił uwagę na powyższe wątpliwości i ,wobec braku prawnych dowodów” wniósł o zniesienie inkwizycji wobec J. Kuplika, czyli umorzenie postępowania karnego w tym zakresie.

Wyrok w sprawie Oszyków sporządzono na urzędowym formularzu i ogłoszono go skazanym w dniu 3 września 1842 r. Stawający byli zobowiązani złożyć oświadczenie co do ewentualnego wniesienia rekursu i potwierdzić je własnoręcznym podpisem. Samuel i Jachet Oszykowie zgodzili się z wyrokiem i złożyli oświadczenie do protokołu, że zrzekają się rekursu, czyli skierowania sprawy do kontroli instancyjnej. Można przypuszczać, iż było to spowodowane przekonaniem skazanych, że skoro Dyrekcja Policji wydała względem nich bardzo łagodny wyrok, to sąd II instancji (Sąd Wyższy) nie znajdzie już żadnych okoliczności łagodzących uzasadniających dalsze złagodzenie kary.

Małżonkowie odmówili jednak podpisania swoich oświadczeń, powołując się na to, że tego dnia był szabat. Świadczy to niewątpliwie o tym, że byli oni narodowości żydowskiej, ale również byli praktykującymi wyznawcami judaizmu. W tej sytuacji stosowną adnotację na formularzu wyroku zamieścił sekretarz Dyrekcji Policji ${ }^{24}$. Trudno jednoznacznie stwierdzić, czy wyżej wymienieni inkry-

${ }^{24}$ Z kolei J. Kuplik oświadczył, że „,poprzestaje na ogłoszonym mu wyroku”, ale odmówił złożenia podpisu na protokole, powołując się na szabat. 
minowani byli analfabetami, gdyż przez odmowę złożenia podpisu rozumiano też odmowę postawienia znaków przez osoby niepiśmienne (chrześcijanie stawiali trzy krzyżyki, a Żydzi - trzy kółka).

$\mathrm{Z}$ dalszych adnotacji zamieszczonych na formularzu wyroku w sprawie Oszyków wynika, że Dyrekcja Policji poleciła komisarzowi policji w cyrkule V przymusowe doprowadzenie skazanych do aresztu ${ }^{25}$. Niewątpliwie właśnie tam zamieszkiwali ${ }^{26}$.

Jachet Oszyk została doprowadzona do aresztu w dniu 2 października $1842 \mathrm{r}$. o godzinie 10:30. Po odbyciu kary, w dniu 2 listopada 1842 r., opuściła areszt. Z kolei wobec Samuela Oszyka z nieznanych powodów w dniu 7 grudnia 1842 r. na mocy ustnego polecenia dyrektora policji wstrzymano wykonanie kary. Dopiero w dniu 20 grudnia 1842 r. o godzinie 9:00 Samuel Oszyk zgłosił się do aresztu. Po odbyciu kary, w dniu 20 stycznia 1843 r., opuścił aresz $t^{27}$.

Powyższa historia dotycząca zawarcia małżeństwa rytualnego przez Izraelitów bez poprzedzającego ślubu cywilnego, tj. popełnienia ciężkiego przestępstwa policyjnego ,przeciwko obyczajności publicznej” z § 252 cz. 2 k.k., nie była odosobniona. We wskazanych wcześniej aktach Dyrekcji Policji znajduje się jeszcze kilkanaście innych wyroków dotyczących tego rodzaju spraw, które zapadły w 1842,1844 i 1845 r. ${ }^{28}$

Należy podkreślić, że tylko w sprawie Oszyków zapadł aż tak łagodny wyrok, w wysokości jedynie jednego miesiąca aresztu. Co prawda, był on obostrzony postem o chlebie i wodzie, lecz z punktu widzenia skazanych była to niewątpliwie mniejsza dolegliwość niż kilkumiesięczny areszt. W pozostałych sprawach, w których Dyrekcja Policji orzekała na gruncie ustawy z 1821 r., wymierzono oskarżonym karę po $83 \mathrm{dni}$ aresztu ${ }^{29}$. W przypadku popełnienia przestępstwa z $§ 252$ cz. 2 k.k. w czasie obowiązywania ustawy z 1838 r. Dyrekcja orzekała karę sześciu miesięcy aresztu ${ }^{30}$, natomiast tym, którzy zostali skazani na podstawie ustawy z 1844 r., Dyrekcja Policji wymierzyła karę trzech miesięcy aresztu ${ }^{31}$.

${ }^{25}$ ANKr, WMK - III/18/15, k. 971-976, nr 13688.

${ }^{26}$ V cyrkuł obejmował dawniejszą gminę VI Stradom i chrześcijański Kazimierz oraz gminy X i XI, położone na krakowskim Kazimierzu. Zob. P. Cichoń, op. cit., s. 28.

${ }^{27}$ Tym samym sprawa została zakończona, a wymierzona kara - wyegzekwowana. W dniu 21 stycznia 1843 r. akta sprawy odesłano do archiwum Dyrekcji Policji.

${ }^{28}$ P. Cichoń, op. cit., s. 405-407.

${ }^{29}$ Wyrok z dnia 11 czerwca 1842 r., nr 9081, ANKr, WMK - III/18/15, k. 817-822; wyrok z dnia 22 czerwca 1842 r., nr 9908, WMK - III/18/15, k. 743-745; wyrok z dnia 27 lipca 1842 r., nr 11064, ANKr, WMK - III/18/15, k. 339-345; wyrok z dnia 9 lutego 1844 r., nr 1674, ANKr, WMK - III/18/13, k. 558; wyrok z dnia 20 lutego 1844 r., nr 2210, ANKr, WMK - III/18/13, k. 566; wyrok z dnia 5 marca 1844 r., nr 3194, ANKr, WMK - III/18/13, k. 591; wyrok z dnia 23 lipca 1844 r., nr 9756, ANKr, WMK - III/18/15, k. 1007-1009; wyrok z dnia 13 grudnia 1844 r., nr 18788, ANKr, WMK - III/18/15, k. 1007-1009.

${ }^{30}$ Wyrok z 1844 r., nr 13869, ANKr, WMK - III/18/15, k. 677-692.

${ }^{31}$ Wyrok z dnia 11 listopada 1845 r., nr 3066, 6490, 10037, 22293, ANKr, WMK - III/18/15, 
Warto zauważyć, że we wszystkich udokumentowanych sprawach z 1842 i 1844 r. skazani za zawarcie rytualnego małżeństwa bez wcześniejszego ślubu cywilnego otrzymywali karę aresztu, choć pierwszoplanową karą przewidzianą w ustawach była kara pieniężna. Nasuwa się zatem logiczny wniosek, że powodem wymierzenia właśnie takiej kary był fakt, iż z powodu ubóstwa skazanych nie było realnej szansy na wyegzekwowanie kary pieniężnej. W związku z tym, aby wymierzona kara faktycznie odegrała rolę represyjną wobec nich, a zarazem i prewencyjną wobec innych osób, zasadne było orzekanie od razu kary aresztu.

W związku z powyższym nie będzie błędem postawienie tezy, że powodem zawierania przez skazanych jedynie małżeństw religijnych było ubóstwo, przez które przyszli małżonkowie nie mogli spełnić wymogów formalnych do uzyskania administracyjnego zezwolenia na zawarcie małżeństwa cywilnego. Można przypuszczać, iż takie osoby z premedytacją dopuszczały się tego rodzaju przestępstwa, godząc się na poniesienie odpowiedzialności karnej. Była to zapewne dla nich jedyna szansa na założenie rodziny i pozostawanie w zgodzie ze swoim sumieniem oraz wskazaniami wyznawanej religii.

Problem zasygnalizowany w niniejszym artykule pokazuje również, że formalne zakazy i ograniczenia praw cywilnych ludności żydowskiej, do których niewątpliwie należała reglamentacja prawna zawierania przez nich związków małżeńskich, nie stanowiły skutecznej przeszkody do uniemożliwienia wzrostu populacji tej ludności w państwie ${ }^{32}$. Właśnie taki cel przyświecał rządzącym w Wolnym Mieście Krakowie, którzy dostrzegając nieskuteczność wydawanych przez siebie przepisów, zwiększali restrykcyjność nowych ustaw dotyczących warunków uzyskania konsensu na zawarcie związku małżeńskiego przez Izraelitów oraz dotyczących konsekwencji prawnych za zawarcie potajemnych małżeństw ${ }^{33}$.

k. 541-548; wyrok z dnia 29 sierpnia 1845 r., SW 2895, ANKr, WMK - III/18/15, k. 253; wyrok z dnia 3 października 1845 r., nr 10555, 17622, 18374, ANKr, WMK - III/18/15, k. 505-507.

${ }^{32}$ W 1815 r. pośród 23387 mieszkańców Krakowa 4876 osób deklarowało wyznanie mojżeszowe. U schyłku Wolnego Miasta Krakowa - w 1843 r. - ich grono oszacowano na 13080 osób. Szybki przyrost naturalny wśród ludności żydowskiej wynikał ze wskazań religijnych („Bądźcie płodni i rozmnażajcie się") oraz na skutek napływu emigrantów z państw ościennych. Zob. A. Jakimyszyn, op. cit., s. 53-55.

${ }^{33}$ Przepisy ustawy z $1821 \mathrm{r}$. nie zmieniły istniejącego stanu rzeczy, tj. zawierania potajemnych małżeństw. W 1822 r. krakowscy Żydzi zawarli jedynie 31 legalnych małżeństw. Rok później ich liczba wzrosła do 44. W 1824 r. było ich 44, 1825 r. - 55, 1826 r. - 61, 1827 r. - 68, 1828 r. 57, 1829 r. $-56,1830$ r. -46 . W drugiej połowie lat 30. XIX w. nastąpił wyraźny spadek liczby rejestrowanych ślubów, do poziomu, jaki nie występował w latach poprzednich. Liczba legalnych żydowskich małżeństw zawartych przez mieszkańców Krakowa w latach 1831-1838 wynosiła w 1831 r. $-50,1832$ r. $-82,1833$ r. $-80,1834$ r. $-75,1835$ r. $-32,1836$ r. $-0,1837$ r. $-46,1838$ r. - 14. Zob. ibidem, s. 86-93; B. Małecka, op. cit., s. 575. 


\section{BIBLIOGRAFIA}

Akta Dyrekcji Policji Wolnego Miasta Krakowa 1818-1848, WMK-III/18/13, WMK-III/18/14, WMK-III/18/15, [w:] Archiwum Narodowe w Krakowie, Ekspozytura w Spytkowicach (źródła rękopiśmienne).

Bartel W.M., Ustrój i prawo Wolnego Miasta Krakowa (1815-1846), Kraków 1976.

Cichoń P., Dyrekcja Policji Wolnego Miasta Krakowa 1827-1846. Studium historyczno-prawne, Kraków 2014.

Dziadzio A., Powszechna historia prawa, Warszawa 2008.

„Dziennik Praw”, Kraków 1838, 1839, 1840, 1842, 1844.

„Dziennik Praw Rzeczypospolitej Krakowskiej”, Kraków 1827.

„Dziennik Rozporządzeń Rządowych Wolnego, Niepodległego i ściśle Neutralnego Miasta Krakowa i Jego Okręgu", Kraków 1817, 1822.

„Dziennik Rządowy Wolnego Miasta Krakowa i Jego Okręgu”, Kraków 1839.

Jakimyszyn A., Żydzi krakowscy w dobie Rzeczypospolitej Krakowskiej. Status prawny, przeobrażenia gminy, system edukacyjny, Kraków - Budapeszt 2008.

Korobowicz A., Witkowski W., Funkcje sądowe organów administracji lokalnej w Księstwie Warszawskim i Królestwie Polskim, „Czasopismo Prawno-Historyczne” 1993, t. 45, z. 1-2.

Księga ustaw na zbrodnie i ciężkie policyjne przestępstwa, cz. 1: O zbrodniach, cz. 2: Księga ustaw o ciężkich przestępstwach policyjnych i o sposobie z temiz postępowania, Kraków 1804.

Małecka B., Sytuacja prawna ludności żydowskiej w Rzeczypospolitej Krakowskiej w świetle rozporzadzeń rządowych, ,Studia Historyczne” 1991.

Małecki J.M., Żydzi krakowscy w XIX wieku, wyjście z getta, [w:] Wspólnoty lokalne i środowiskowe w miastach i miasteczkach ziem polskich pod zaborami i po odzyskaniu niepodległości. Studia nad dziejami miast i mieszczaństwa, Toruń 1998.

Pauli L., Austriacki kodeks karny z 1803 r. w Wolnym Mieście Krakowie (1815-1833), cz. 1, „Zeszyty Naukowe Uniwersytetu Jagiellońskiego. Prace Prawnicze” 1968, z. 40.

Pauli L., Austriacki kodeks karny z 1803 r.w Wolnym Mieście Krakowie (1815-1833), cz. 2, „Zeszyty Naukowe Uniwersytetu Jagiellońskiego. Prace Prawnicze” 1970, z. 46.

Salmonowicz S., Prawo karne oświeconego absolutyzmu. Z dziejów kodyfikacji karnych przełomu XVIII/XIX w., Toruń 1966.

Sobociński W., Historia ustroju i prawa Księstwa Warszawskiego, Toruń 1964.

Statut organiczny dla władz sądowych kraju Wolnego Miasta Krakowa z dnia 25 stycznia 1842 r. (Dz. Praw z 1842 r., nr 3 D.K.).

Statut urządzający Dyrekcję Policji Wolnego Miasta Krakowa z dnia 18 lutego 1840 r. (Dz. Praw z 1840 r., nr 10 D.K.).

Wachholz S., Akty prawne Rewolucji Krakowskiej z roku 1846, „Czasopismo Prawno-Historyczne" 1956 , t. 8, z. 1.

Wachholz S., Rzeczpospolita Krakowska. Okres od 1815 do 1830 r., Warszawa 1957.

Źródła rękopiśmienne (Archiwum Wolnego Miasta Krakowa - zespół nr 200).

\section{SUMMARY}

The article shows the judicial activity in the Directorate of Police of the Free City of Cracow on the example of the Oszyk's case from 1842 - a Jewish couple who got married following Jewish rituals without performing the mandatory civil marriage. People getting married in such a way committed a crime categorized as a serious police crime. There are outlined the rules which 
Pobrane z czasopisma Studia Iuridica Lublinensia http://studiaiuridica.umcs.pl Data: 26/04/2023 15:06:29

determined the punishments for such an offense. The judicial proceedings in the Oszyk's case are discussed. There are also highlighted other cases of similar type conducted in the Directorate of Police in 1842, 1844 and 1845.

Keywords: Free City of Cracow; administration; the judiciary; the Police Directorate; ritual Jewish marriage; criminal law 